\title{
Studies of the Mechanism by Which Phosphate Infusion Lowers Serum Calcium Concentration*
}

\author{
Lee A. Hebert, $\dagger$ Jacob Lemann, Jr. + John R. Petersen, and \\ EDWARD J. LENNON \\ (From the Department of Medicine and the Clinical Research Center, Marquette University \\ School of Medicine and Milwaukee County General Hospital, Milwaukee, Wisc.)
}

It has long been known that oral or intravenous administration of phosphate salts lowers the serum calcium concentration in normal animals $(1,2)$ and in hypercalcemic human subjects (3-5). Recently, interest has been renewed in the clinical use of phosphate therapy to control life-threatening hypercalcemia because of the relative ineffectiveness or toxicity of other modes of therapy $(6,7)$. In 1962, Dent (5) reported dramatic lowering of the serum calcium concentration in a patient with hyperparathyroidism during the intravenous infusion of sodium phosphate and sustained lowering of serum calcium by continuing oral doses of phosphate in another patient with hyperparathyroidism. Since then, Goldsmith and Ingbar (8) have demonstrated the clinical effectiveness and apparent safety of both oral and intravenous phosphate therapy in the management of hypercalcemia accompanying a variety of diseases. Most of the investigators who have shown that phosphate administration lowers serum calcium concentration have suggested that this effect is the result of the precipitation of calcium phosphate salts in the body. The present studies were carried out to further test this hypothesis.

If phosphate infusion lowers serum calcium concentration by causing calcium phosphate salt precipitation, then $a$ ) phosphate infusion should

\footnotetext{
* Submitted for publication April 29, 1966; accepted September 1, 1966.

This investigation was supported in part by grants R01 AM 08924 and 5 M01 FR-00058, both from the U. S. Public Health Service.

$\dagger$ Work done during tenure as a fellow in the Department of Medicine, Renal Service, Marquette University School of Medicine, and supported by U. S. Public Health Service training grant 2T1 AM-5023-11 (e).

$¥$ Address requests for reprints to Dr. Jacob Lemann, Jr., Dept. of Medicine, Marquette University School of Medicine, Milwaukee County General Hospital, 8700 West Wisconsin Avenue, Milwaukee, Wisc. 53226.
}

tend to lower serum calcium concentration in all subjects, regardless of the presence or absence of those endocrine organs normally involved in the regulation of the serum calcium; $b$ ) a simultaneous increase in calcium excretion should not account for the fall in serum calcium occurring during phosphate infusion; and $c$ ) the degree by which serum calcium concentrations fall should be a function of the extent to which the solubility product of some calcium phosphate salt is exceeded during the infusion of phosphate.

The results of the present experiments satisfy all of these postulates and strongly support the hypothesis that phosphate infusion lowers serum calcium concentration as a result of $\mathrm{CaHPO}_{4}$ precipitation.

\section{Methods}

Studies were carried out in 22 patients divided into four groups: 1) eight control subjects without disorders of calcium homeostasis, 2) three patients with hypoparathyroidism on adequate calcium and vitamin D therapy, 3) four patients with primary hyperparathyroidism, and 4) seven patients with hypercalcemia in association with malignant tumors of the breast or lung or with multiple myeloma. All were hospitalized in the Marquette University Clinical Research Center, where they received constant diets. Calcium and phosphorus intakes were constant for each subject but varied from subject to subject, ranging from 10 to 26 mmoles of calcium per day and 24 to 46 mmoles of phosphorus per day.

Venous blood $\mathrm{pH}$, serum $\left[\mathrm{HCO}_{3}{ }^{-}\right]$, and the serum concentrations of calcium, magnesium, phosphorus, and creatinine were measured serially in each subject. Three general protocols were followed: 1) Complete metabolic balance studies for calcium, phosphorus, and magnesium were carried out in one normal subject, one patient with hypoparathyroidism, and two patients with hyperparathyroidism. Observations were made during one 6-day control period and then during a 9-day experimental period. The phosphate infusion was given on the third day of the experimental period to obviate the possibility of the phosphate infusion causing excretion of calcium into the feces distal to the carmine marker used to discriminate the stool periods. 2) Urinary calcium, 
phosphorus, magnesium, and creatinine were measured on 2 to 6 control days, the day of phosphate infusion, and 3 to 6 recovery days in four normal subjects, two patients with hypoparathyroidism, and two patients with hyperparathyroidism as well as three patients with cancer and hypercalcemia. 3) Measurements of blood and serum constituents alone were made during 2 to 3 control days, the day of phosphate infusion, and 3 to 5 recovery days in three normal subjects and four patients with malignant disease and hypercalcemia.

After control observations, each subject was infused with 1 to 2.8 mmoles of phosphate per kilogram of body weight over 6 hours. The quantity of phosphate infused was deliberately varied among the subjects in each group to produce varying serum phosphorus concentrations. All infusions were begun at 9:00 a.m. with the subjects in the fasting state. The phosphate was given as a theoretically neutral and isotonic solution containing 80.6 mmoles $\mathrm{N}_{2} \mathrm{HPO}_{4} \cdot 7 \quad \mathrm{H}_{2} \mathrm{O}$ and 20.1 mmoles $\mathrm{KH}_{2} \mathrm{PO}_{4}$. This solution actually had a $\mathrm{pH}$ of 7.38 and osmolality of $240 \mathrm{mOsm}$ per $\mathrm{kg}$.

Blood samples were drawn at $1,3,6,12$, and 24 hours after the infusion was begun. Thereafter, additional specimens were obtained at 36 hours in some subjects and daily in all subjects until the study was completed. The urine excreted during the 6 hours of phosphate infusion was collected separately to allow calculation of mean tubular phosphate reabsorption from the mean serum $[\mathrm{P}]$ during the infusion.

Calcium and magnesium in serum, urine, and ashed samples of stool and diet were measured by atomic absorption spectrophotometry. We added lanthanum to the diluent used in the determination of calcium to suppress phosphate interference. Phosphorus was measured in serum, urine, and in $\mathrm{H}_{2} \mathrm{SO}_{4}-\mathrm{H}_{2} \mathrm{O}_{2}$ digests of stool and diet by the standard autoanalyzer method. Serum $\left[\mathrm{HPO}_{4}^{-}\right]$was calculated from serum total $[\mathrm{P}]$ and blood $\mathrm{pH}$ assuming $\mathrm{pk}_{2}{ }_{2}$ for phosphate $=6.8$. Creatinine in serum and urine was also measured with the autoanalyzer. Blood $\mathrm{pH}$ was measured with a Radiometer $\mathrm{pH}$ meter with a capillary glass electrode, and total serum $\mathrm{CO}_{2}$ content was measured manometrically. Ultra- filtrates of serum for determination of ultrafilterable calcium were prepared at $37^{\circ} \mathrm{C}$ by the method of Toribara, Terepka, and Dewey (9), modified by handling the serum samples anaerobically and equilibrating each specimen with different $\mathrm{CO}_{2}$ in air mixtures, saturated with water vapor at $37^{\circ} \mathrm{C}$, to produce a $\mathrm{PCO}_{2}$ as close as possible to that calculated from the original measurements of $\mathrm{pH}$ and total $\mathrm{CO}_{2}$ content.

The variance in results is given as the mean plus or minus $1 \mathrm{SD}$ throughout the manuscript.

\section{Results}

The upper part of Table I presents mean body weight and mean serum total calcium ([Ca]), phosphorus ( $[\mathrm{P}])$, magnesium $([\mathrm{Mg}])$, and creatinine levels for each group during control observations. Body weight was comparable in all groups. The normal serum total [Ca] and [P] in the hypoparathyroid group demonstrate that adequate therapy with calcium and vitamin $\mathrm{D}$ was being given. The degree of hypercalcemia in the patients with hyperparathyroidism was slightly less than that observed in the patients with malignant diseases, but the difference between the mean serum total $[\mathrm{Ca}]$ for these groups was not significant $(p<0.1)$. As expected, serum $[P]$ was low in the patients with hyperparathyroidism and normal in the patients with cancer and hypercalcemia. Serum $[\mathrm{Mg}]$ concentrations were normal in all groups. ${ }^{1}$ The serum creatinine concentration was slightly elevated in each of the patients with hypoparathyroidism and, since two of the patients with cancer and hypercalcemia were moderately azotemic, mean serum creatinine concentration for this group was also elevated.

\footnotetext{
${ }^{1}$ Normal serum $[\mathrm{Mg}]$ in our laboratory $=0.89 \pm 0.06$ mmole per $L(n=24)$.
}

TABLE I

Mean control observations

\begin{tabular}{|c|c|c|c|c|}
\hline Condition of subject & Normal & Hypoparathyroid & Hyperparathyroid & $\begin{array}{c}\text { Cancer and } \\
\text { hypercalcemia }\end{array}$ \\
\hline $\begin{array}{l}\text { Number of subjects } \\
\text { Body weight }(k g) \\
\text { Serum total }\end{array}$ & $61 \stackrel{8}{ \pm 13}$ & $\begin{array}{c}3 \\
62 \pm 14\end{array}$ & $78 \pm \stackrel{4}{18}$ & $58 \pm 6$ \\
\hline $\begin{array}{l}\mathrm{Ca}(\text { mmoles } / L) \\
\mathrm{P}(\text { mmoles } / L) \\
\mathrm{Mg}(\text { mmoles } / L) \\
\text { Creatinine }(\mathrm{mg} / 100 \mathrm{ml})\end{array}$ & $\begin{array}{l}2.34 \pm 0.15 \\
1.04 \pm 0.15 \\
0.88 \pm 0.06 \\
1.0 \pm 0.2\end{array}$ & $\begin{array}{l}2.49 \pm 0.38 \\
1.33 \pm 0.35 \\
0.86 \pm 0.07 \\
1.6 \pm 0.1\end{array}$ & $\begin{array}{l}3.04 \pm 0.36 \\
0.82 \pm 0.13 \\
0.92 \pm 0.12 \\
1.1 \pm 0.4\end{array}$ & $\begin{array}{l}3.60 \pm 0.50 \\
1.20 \pm 0.27 \\
0.83 \pm 0.21 \\
2.2 \pm 1.7\end{array}$ \\
\hline $\begin{array}{l}\text { Number of subjects } \\
\text { Urine } \\
\mathrm{Ca} \text { (mmoles } / \text { day) } \\
\mathrm{P} \text { (mmoles/day) } \\
\mathrm{Mg} \text { (mmoles/day) } \\
\text { Creatinine clearance ( } L / \text { day })\end{array}$ & $\begin{array}{r}3.2 \pm 1.0 \\
19.6 \pm 5.5 \\
4.6 \underset{126}{ \pm} 2.5\end{array}$ & $\begin{aligned} 6.5 & \pm 3.2 \\
24.8 & \pm 4.5 \\
4.8 & \pm 2.0\end{aligned}$ & $\begin{aligned} 7.8 & \pm 3.0 \\
18.2 & \pm 11.5 \\
4.5 & \pm 2.1 \\
111 & \end{aligned}$ & $\begin{array}{r}14.8 \pm 3.8 \\
13.7 \pm 6.3 \\
5.2 \text { 声 } 2.6\end{array}$ \\
\hline
\end{tabular}



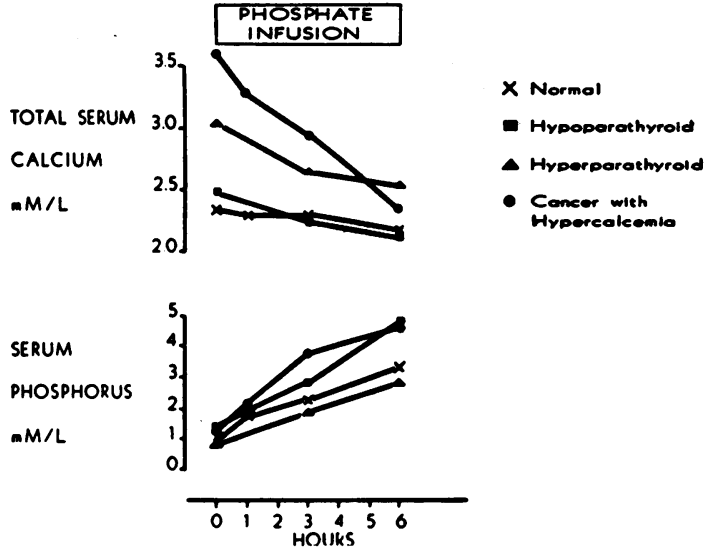

Fig. 1. The efFect of Phosphate INFUSION ON tOtal SERUM CALCIUM AND PHOSPHORUS LEVELS.

The lower portion of Table I gives the mean control urinary calcium, phosphorus, and magnesium excretion rates and 24-hour endogenous creatinine clearance for those patients in each group in whom these observations were made. Urinary calcium excretion was, on the average, at the upper limits of normal in the patients with treated hypoparathyroidism and increased in the patients with hyperparathyroidism and the patients with cancer. Many of the patients with malignant diseases were anorectic and were therefore given less food than the patients in the other groups. This probably accounts for the lower urinary phosphorus excretion in the patients with cancer. Urinary magnesium excretion was comparable in all groups.

Figure 1 shows the mean serum total $[\mathrm{Ca}]$ and serum $[\mathrm{P}]$ for each group before, during, and at the end of phosphate infusion. Data for each individual subject are presented in Table II. As shown in Figure 1 and Table II, serum [P] rose significantly in each patient and was accompanied

TABLE II

The effect of phosphate infusion on serum total calcium and phosphorus

\begin{tabular}{|c|c|c|c|c|c|c|c|c|c|c|}
\hline \multirow[b]{2}{*}{ Group } & \multirow[b]{2}{*}{ Subject } & \multirow[b]{2}{*}{$\underset{\text { infused }}{P}$} & \multicolumn{4}{|c|}{ Serum total $[\mathrm{Ca}]$} & \multicolumn{4}{|c|}{ Serum $[P]$} \\
\hline & & & Control & $\begin{array}{l}\text { At end } \\
\text { infusion }\end{array}$ & 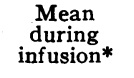 & $\Delta \dagger$ & Control & $\begin{array}{l}\text { At end } \\
\text { infusion }\end{array}$ & $\begin{array}{c}\text { Mean } \\
\text { during } \\
\text { infusion* }\end{array}$ & $\Delta \dagger$ \\
\hline & & mmoles $/ \mathbf{k g}$ & \multicolumn{4}{|c|}{ mmoles $/ L$} & \multicolumn{4}{|c|}{ mmoles $/ L$} \\
\hline \multirow[t]{9}{*}{ Normal } & J.K. & 1.24 & 2.56 & 2.42 & 2.48 & -0.14 & 1.06 & 2.55 & 2.00 & +1.49 \\
\hline & J.C. & 1.93 & 2.40 & 2.27 & 2.37 & -0.13 & 0.99 & 2.97 & 2.26 & +1.98 \\
\hline & G.W. & 1.71 & 2.40 & 2.31 & 2.42 & -0.09 & 1.28 & 3.87 & 2.34 & +2.59 \\
\hline & C.B. & 1.32 & 2.36 & 2.18 & 2.28 & -0.18 & 1.00 & 3.45 & 2.06 & +2.45 \\
\hline & E.L. & 1.46 & 2.10 & 2.01 & 2.07 & -0.09 & 0.90 & 2.10 & 1.89 & +1.20 \\
\hline & W.M. & 2.02 & 2.14 & 1.88 & 2.00 & -0.26 & 0.88 & 3.23 & 2.00 & +2.35 \\
\hline & A.H. & 2.25 & 2.44 & 2.17 & 2.31 & -0.27 & 0.94 & 4.06 & 3.03 & +3.12 \\
\hline & W.S. & 2.58 & 2.36 & 2.08 & 2.25 & -0.28 & 1.20 & 3.52 & 2.94 & +2.32 \\
\hline & $\begin{array}{r}\text { Group mean } \\
p\end{array}$ & $1.81 \pm 0.47$ & $2.34 \pm 0.15$ & $2.16 \pm 0.15$ & $2.27 \pm 0.17$ & $\begin{array}{l}-0.18 \pm 0.08 \\
<0.001\end{array}$ & $1.04 \pm 0.15$ & $3.22 \pm 0.66$ & $2.32 \pm 0.44$ & $\begin{array}{l}+2.19 \pm 0.61 \\
<0.001\end{array}$ \\
\hline \multirow[t]{4}{*}{ Hypoparathyroid } & B.J. & 1.38 & 2.86 & 2.38 & 2.60 & -0.48 & 1.31 & 3.05 & 2.00 & +1.74 \\
\hline & L.K. & 1.34 & 2.10 & 1.77 & 1.90 & -0.33 & 1.70 & 5.81 & 3.30 & +4.11 \\
\hline & I.B. & 1.83 & 2.50 & 2.29 & 2.35 & -0.21 & 0.99 & 4.71 & 3.03 & +3.72 \\
\hline & $\begin{array}{r}\text { Group mean } \\
\text { p }\end{array}$ & $1.52 \pm 0.27$ & $2.49 \pm 0.38$ & $2.15 \pm 0.33$ & $2.28 \pm 0.35$ & $\begin{array}{l}-0.34 \pm 0.14 \\
<0.025\end{array}$ & $1.33 \pm 0.35$ & $4.52 \pm 1.39$ & $2.78 \pm 0.69$ & $\begin{array}{l}+3.19 \pm 1.27 \\
<0.05\end{array}$ \\
\hline \multirow[t]{5}{*}{ Hyperparathyroid } & М.H. & 1.00 & 2.96 & 2.64 & 2.80 & -0.32 & 0.91 & 2.55 & 1.88 & +1.64 \\
\hline & A.S. & 1.60 & 2.75 & 2.15 & 2.23 & -0.60 & 0.88 & 3.45 & 2.87 & +2.57 \\
\hline & M.W. & 1.19 & 3.56 & 2.98 & 3.15 & -0.58 & 0.63 & 2.45 & 1.42 & +1.82 \\
\hline & R.S. & 1.71 & 2.89 & 2.45 & 2.55 & -0.44 & 0.87 & 4.74 & 2.42 & +3.87 \\
\hline & $\begin{array}{r}\text { Group mean } \\
\text { p }\end{array}$ & $1.38 \pm 0.34$ & $3.04 \pm 0.36$ & $2.56 \pm 0.35$ & $2.68 \pm 0.39$ & $\begin{array}{l}-0.48 \pm 0.13 \\
<0.005\end{array}$ & $0.82 \pm 0.13$ & $3.30 \pm 1.06$ & $2.15 \pm 0.63$ & $\begin{array}{l}+2.48 \pm 1.01 \\
<0.025\end{array}$ \\
\hline \multirow{8}{*}{$\begin{array}{l}\text { Cancer and } \\
\text { hypercalcemia }\end{array}$} & A.G. & 2.67 & 3.34 & 2.06 & 2.56 & -1.28 & 1.14 & 5.65 & 3.48 & +4.51 \\
\hline & A.M. & 2.80 & 3.36 & 1.86 & 2.58 & -1.50 & 0.92 & 5.00 & 3.55 & +4.08 \\
\hline & A.T. & 1.45 & 4.20 & 2.74 & 3.38 & -1.46 & 1.24 & 3.10 & 2.97 & +1.86 \\
\hline & V.R. & 1.83 & 3.75 & 2.94 & 3.26 & -0.81 & 1.10 & 4.26 & 2.66 & +3.16 \\
\hline & F.N. & 1.39 & 4.16 & 2.54 & 3.32 & -1.62 & 1.72 & 4.45 & 3.42 & +2.73 \\
\hline & A.G. & 1.54 & 3.62 & 2.70 & 3.17 & -0.92 & 1.31 & 4.36 & 3.40 & +3.05 \\
\hline & H.W. & 1.92 & 2.76 & 2.44 & 2.64 & -0.32 & 0.97 & 3.24 & 2.41 & +2.27 \\
\hline & $\begin{array}{r}\text { Group mean } \\
p\end{array}$ & $1.94 \pm 0.57$ & $3.60 \pm 0.50$ & $2.47 \pm 0.39$ & $2.99 \pm 0.37$ & $\begin{array}{l}-1.13 \pm 0.47 \\
<0.001\end{array}$ & $1.20 \pm 0.27$ & $4.29 \pm 0.90$ & $3.13 \pm 0.45$ & $\begin{array}{l}+3.09 \pm 0.94 \\
<0.001\end{array}$ \\
\hline
\end{tabular}

* Calculated by plotting the serial blood measurements during the infusion and dividing the area under the resulting curve by time. + Change from control to end infusion. 
by a simultaneous fall in serum total calcium. The infusions were well tolerated, tetany was not observed, and the severely hypercalcemic patients became more alert and physically stronger. The decline in serum total [Ca] in the three patients with hypoparathyroidism, one of whom (B.J.) had also been totally thyroidectomized, was comparable to that in the normal subjects.

Another type of experiment was carried out in two patients with cancer and hypercalcemia to determine how rapidly serum calcium fell when phosphate was infused. When 10 mmoles of phosphate was infused over a 3-minute period, serum total [Ca] fell by 0.46 and 0.35 mmole per L, respectively, during the same brief interval.

Serum ultrafilterable [Ca] was measured in 12 patients just before and at the end of the phosphate infusion. Ultrafilterable [Ca] fell in direct proportion to the fall in total serum $[\mathrm{Ca}]$ and, hence, the per cent of total $[\mathrm{Ca}$ ] that was ultrafilterable did not change. For these subjects, ultrafilterable [Ca] averaged $65 \pm 7 \%$ of total [Ca] before phosphate infusion and $62 \pm 10 \%$ at the end of the infusion. $^{2}$

2 Ultrafilterable calcium for normal subjects in our laboratory averages $60 \pm 3 \%$ of total serum calcium $(\mathrm{n}=$ 20).

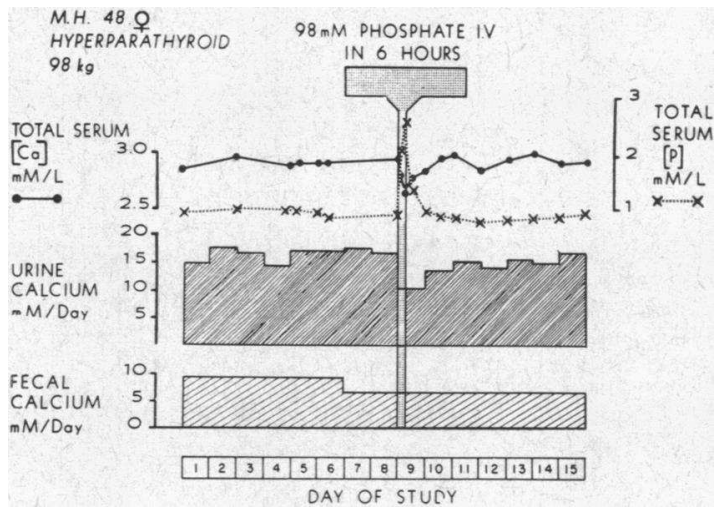

Fig. 2. Serum Calcium and phosphorus leVels and URINARY AND FECAL CALCIUM EXCRETION BEFORE, DURING, AND AFTER PHOSPHATE INFUSION IN A PATIENT WITH HYPERPARATH YROIDISM.

Figure 2 shows the results of a balance study in one patient with hyperparathyroidism and is typical of the responses to phosphate infusion. During the first 6 control days, serum total $[\mathrm{Ca}]$ and serum $[\mathrm{P}]$, shown in the upper part of the Figure, were stable and averaged 2.96 and 0.91 mmoles per L, respectively. Urinary calcium excretion was elevated, averaging 16 mmoles per day. Fecal calcium excretion averaged 9 mmoles per day. On the morning of the ninth balance day, 98 mmoles of phosphate was infused intravenously over a

TABLE III

The effect of phosphate infusion on the daily urinary calcium excretion

\begin{tabular}{|c|c|c|c|c|}
\hline \multirow[b]{2}{*}{ Group } & \multirow[b]{2}{*}{ Subject } & \multicolumn{3}{|c|}{ Urinary calcium } \\
\hline & & $\begin{array}{c}\text { Control } \\
\text { mean }\end{array}$ & $\begin{array}{c}\text { Day of } \\
\text { phosphate } \\
\text { infusion }\end{array}$ & $\begin{array}{l}\text { Day after } \\
\text { phosphate } \\
\text { infusion }\end{array}$ \\
\hline & & & mmoles/day & \\
\hline Normal & $\begin{array}{l}\text { J.K. } \\
\text { J.C. } \\
\text { G.W. } \\
\text { C.B. } \\
\text { J.H. }\end{array}$ & $\begin{array}{l}4.5 \\
3.3 \\
2.2 \\
2.2 \\
3.6\end{array}$ & $\begin{array}{l}4.2 \\
1.6 \\
1.7 \\
1.0 \\
1.9\end{array}$ & $\begin{array}{l}3.6 \\
2.8 \\
2.6 \\
1.8 \\
1.0\end{array}$ \\
\hline Hypoparathyroid & $\begin{array}{l}\text { B.J. } \\
\text { L.K. } \\
\text { A.B; }\end{array}$ & $\begin{array}{l}9.8 \\
6.3 \\
3.4\end{array}$ & $\begin{array}{l}7.1 \\
4.4 \\
1.2\end{array}$ & $\begin{array}{l}7.2 \\
6.0 \\
1.4\end{array}$ \\
\hline Hyperparathyroid & $\begin{array}{l}\text { A.H. } \\
\text { A.S. } \\
\text { M.W. } \\
\text { R.S. }\end{array}$ & $\begin{array}{r}16.2 \\
2.0 \\
9.5 \\
3.4\end{array}$ & $\begin{array}{r}10.5 \\
1.1 \\
5.0 \\
2.2\end{array}$ & $\begin{array}{r}13.8 \\
1.0 \\
5.5 \\
1.2\end{array}$ \\
\hline $\begin{array}{l}\text { Cancer and hypercalcemia } \\
\text { Mean for all subjects } \\
\text { Change from control } \\
\text { p }\end{array}$ & $\begin{array}{l}\text { A.G. } \\
\text { A.M. } \\
\text { A.T. }\end{array}$ & $\begin{array}{r}13.8 \\
19.0 \\
11.7 \\
7.4 \pm 5.6\end{array}$ & $\begin{array}{l}4.1 \\
3.2 \\
2.3 \\
3.4 \pm 2.6 \\
-4.0 \pm 4.4 \\
<0.005\end{array}$ & $\begin{array}{l}2.1 \\
0.3 \\
0.4 \\
3.4 \pm 3.6 \\
-4.0 \pm 5.5 \\
<0.025\end{array}$ \\
\hline
\end{tabular}


TABLE IV

The effect of phosphate infusion on the mean daily fecal calcium content

\begin{tabular}{|c|c|c|c|}
\hline \multirow[b]{2}{*}{ Group } & \multirow[b]{2}{*}{ Subject } & \multicolumn{2}{|c|}{ Stool calcium } \\
\hline & & $\begin{array}{l}\text { Control } \\
\text { period }\end{array}$ & $\begin{array}{l}\text { Phosphate } \\
\text { infusion } \\
\text { period }\end{array}$ \\
\hline & & \multicolumn{2}{|c|}{ mmoles/day } \\
\hline Normal & J.K. & 13.5 & 11.0 \\
\hline Hypoparathyroid & L.K. & 36.0 & 27.0 \\
\hline \multirow[t]{2}{*}{ Hyperparathyroid } & M.H. & 9.0 & 6.5 \\
\hline & A.S. & 4.5 & 4.5 \\
\hline Mean for all subjects & & $15.8 \pm 14.0$ & $12.3 \pm 10.2$ \\
\hline Change from control & & & $-3.5 \pm 3.8$ \\
\hline $\mathrm{p}$ & & & $>0.1$ \\
\hline
\end{tabular}

6-hour period. Serum $[\mathrm{P}]$ rose progressively during the infusion, reaching a peak value of 2.55 mmoles per $\mathrm{L}$ at the end of the infusion. Serum total [Ca] fell reciprocally to a value of 2.64 mmoles per $\mathrm{L}$ at the end of the infusion. Urinary calcium excretion on the day of infusion and the following day fell below control levels. The cumulative excretion of calcium in both urine and feces in the period during which the phosphate was infused was less than that noted in the control period. After the phosphate infusion was completed, serum $[\mathrm{P}]$ fell to control values within 18 hours. Serum total $[\mathrm{Ca}]$ returned to the control levels 30 hours after the infusion was completed.

As shown in Table III urinary calcium excretion declined in each of 15 subjects after phosphate infusion. For the group, urinary calcium fell significantly from an average of $7.4 \pm 5.6$ mmoles per day during control to $3.4 \pm 2.6$ and $3.4 \pm 3.6$

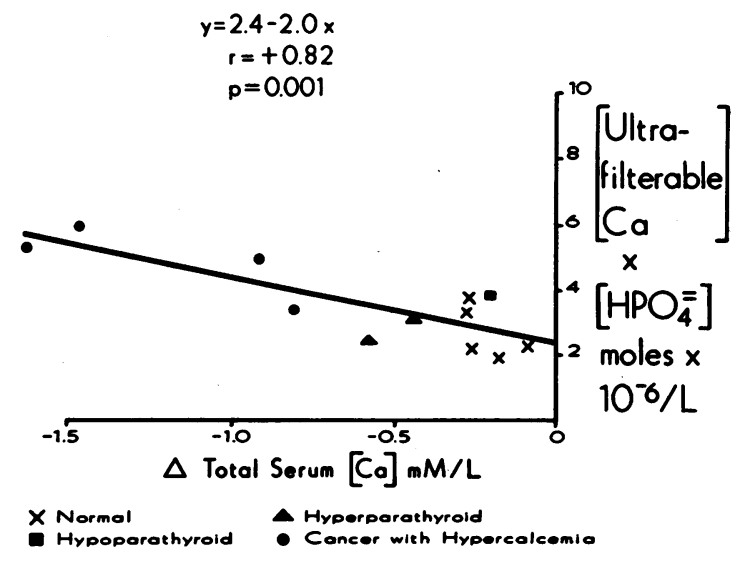

Fig. 3. The Relationship BETWEen the fall iN toTAL SERUM CALCIUM LEVEL AT THE END OF PHOSPHATE INFUSION AND THE MEAN ULTRAFILTERABLE SERUM CALCIUM $\times \mathrm{HPO}_{4}=$ MOLAR PRODUCT DURING INFUSION. mmoles per day on the day of and the day after phosphate infusion, respectively.

As shown in Table IV fecal calcium did not increase. Instead, a small decrease was found in three of the four subjects whose stools were analyzed. For the group fecal calcium declined from $15.8 \pm 14.0$ mmoles per day during control to $12.3 \pm 10.2$ mmoles per day in the metabolic period during which phosphate was infused.

Figure 3 shows the relationship between the mean molar product of serum ultrafilterable [Ca] times $\left[\mathrm{HPO}_{4}{ }^{=}\right]$during each infusion and the observed fall of total serum [Ca] in the 12 subjects of the present study in whom these measurements were made. It is known that ultrafilterable calcium is almost entirely ionized, and it has been

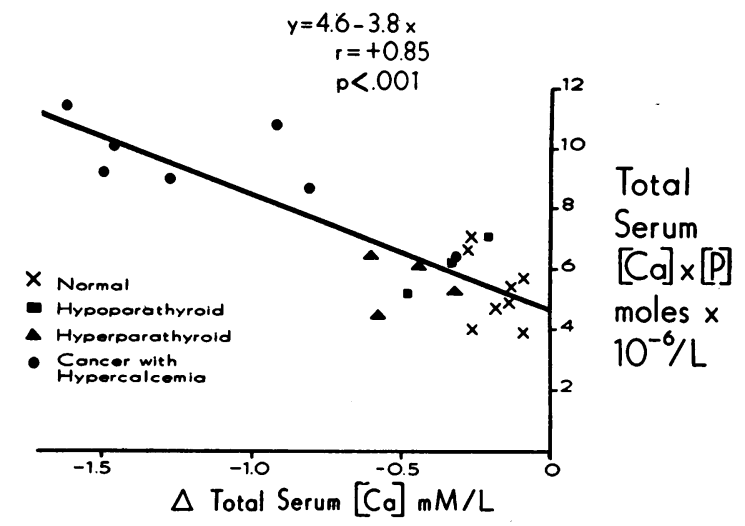

Fig. 4. The Relationship BetWeen the Fall iN TOTAL SERUM CALCIUM LEVEL AT THE END OF PHOSPHATE INFUSION AND THE MEAN TOTAL SERUM CALCIUM $X$ PHOSPHORUS MOLAR PRODUCT DURING INFUSION.

shown that phosphate levels comparable to those achieved in the present study do not significantly increase the fraction of ultrafilterable calcium that is complexed (10). Thus, the molar product of ultrafilterable calcium times $\left[\mathrm{HPO}_{4}{ }^{\circ}\right]$ is a close estimate of $\left[\mathrm{Ca}^{++}\right] \times\left[\mathrm{HPO}_{4}{ }^{\circ}\right]$. As shown in Figure 3, serum total [Ca] fell in direct linear proportion to the magnitude of the mean ultrafilterable $[\mathrm{Ca}] \times\left[\mathrm{HPO}_{4}{ }^{=}\right]$molar product during each infusion.

Since total serum calcium may be considered proportional to ionized calcium and total serum phosphorus may be considered proportional to $\left[\mathrm{HPO}_{4}{ }^{=}\right]$, the molar product of total serum [Ca] $X$ total serum $[\mathrm{P}]$ can be taken as a crude but clinically useful estimate of the $\left[\mathrm{Ca}^{++}\right] \times\left[\mathrm{HPO}_{4}{ }^{2}\right]$ molar product. Figure 4 shows a plot of mean 


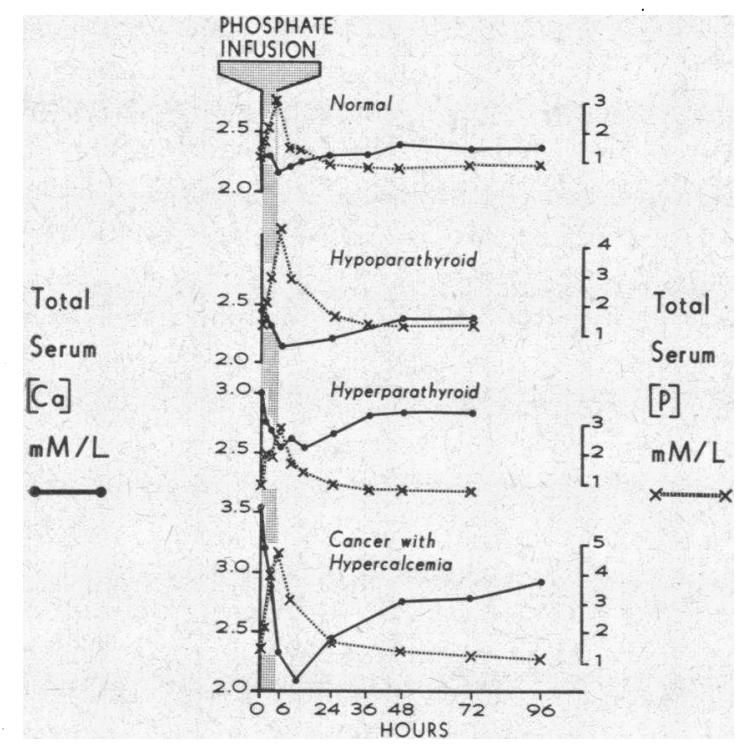

Fig. 5. MEAN total SERUM CALCIUM AND PHOSPHORUS LEVELS BEFORE, DURING, AND AFTER PHOSPHATE INFUSION.

serum total $[\mathrm{Ca}] \times$ mean serum total $[\mathrm{P}]$ for each of the 22 subjects during phosphate infusion vs. the observed fall in total serum [Ca]. Good linear correlation is again apparent.

Figure 5 shows the mean serum total [Ca] and serum $[\mathrm{P}]$ for each group before, during, and after phosphate infusion. Again, it can be seen that serum total [Ca] fell simultaneously in each group as serum $[\mathrm{P}]$ was raised by phosphate infusion. After the infusions were stopped, serum $[\mathrm{P}]$ returned to control levels within 24 hours in each group. In the normal subjects, serum total [Ca] also returned promptly to control values within 18 hours. In the remaining groups, control serum total [Ca] was not restored until 42 , greater than 70 , and greater than 96 hours for the patients with hypoparathyroidism, hyperparathyroidism, and cancer, respectively.

The slow return of the serum total [Ca] to control values in the patients with hypoparathyroidism was thought to be due to the absence of parathyroid hormone and hence inability to mobilize calcium from tissue stores. It seemed possible that a delayed response of the parathyroid glands might also have accounted for the slow rise in the serum total [Ca] in the patients with hyperparathyroidism and those with cancer. Renal tubular phosphate reabsorption was thus examined as indirect evidence of parathyroid activity.

Figure 6 shows the mean tubular reabsorption of phosphate per $100 \mathrm{ml}$ glomerular filtration rate (GFR) (estimated from endogenous creatinine clearance) for each group during control observations and during and after phosphate infusion. These calculations were made for each subject whose urine was analyzed (Table I). During control observations, the renal tubular reabsorption of phosphate was comparable for the normal, hypoparathyroid, and cancer groups, averaging $90 \pm$ $16,93 \pm 39$, and $92 \pm 12 \mu$ moles per $100 \mathrm{ml} \mathrm{GFR}$, respectively. As expected, tubular phosphate reabsorption was significantly lower in the patients with hyperparathyroidism than in the control subjects, averaging $66 \pm 8 \mu$ moles per $100 \mathrm{ml}$ GFR $(\mathrm{p}<0.05)$. During the 6 hours of the phosphate infusion, renal tubular phosphate reabsorption did not change significantly in the normal subjects $(\overline{\mathrm{d}}=+9 \pm 22 \mu$ moles per $100 \mathrm{ml} \mathrm{GFR}$, $p>0.2$ ) but rose sharply in each subject of the remaining three groups $(\overline{\mathrm{d}}=+57 \pm 35 \mu$ moles per $100 \mathrm{ml}$ GFR, $\mathrm{p}<0.005$ ).

After phosphate infusion, tubular phosphate reabsorption in the normal subjects was clearly less during the first recovery day than that found in control observations $(\overline{\mathrm{d}}=-22 \pm 16 \mu$ moles per $100 \mathrm{ml}$ GFR, $\mathrm{p}<0.05$ ) but was not significantly different from control on the second and third recovery days. Similarly, tubular reabsorption of phosphate was below control during the first recovery day in the patients with cancer and hypercalcemia $(\overline{\mathrm{d}}=-26 \pm 9 \mu$ moles per $100 \mathrm{ml}$ GFR, $p<0.025)$ and also on the second recovery day $(\overline{\mathrm{d}}=-23 \pm 3 \mu$ moles per $100 \mathrm{ml}$ GFR, $\mathrm{p}<$ $0.005)$. By contrast, during the recovery days tubular phosphate reabsorption was not different

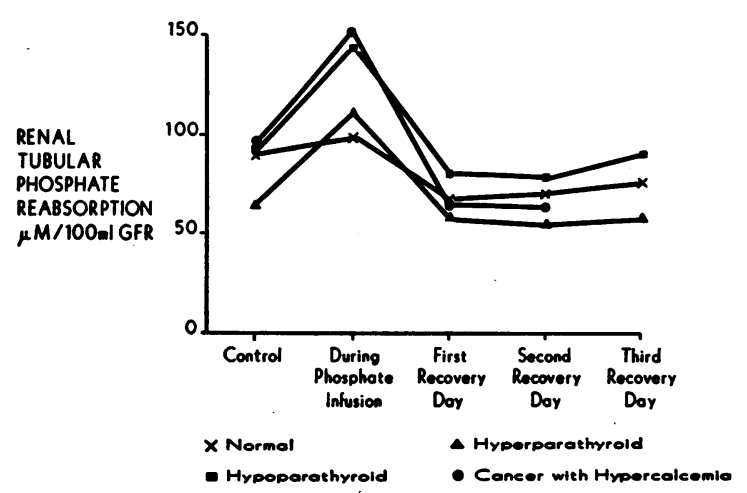

Fig. 6. Renal tUbUlar PHOSPHATE REABSORPtion BEFORE, DURING, AND AFTER PHOSPHATE INFUSION. GFR = glomerular filtration rate. 


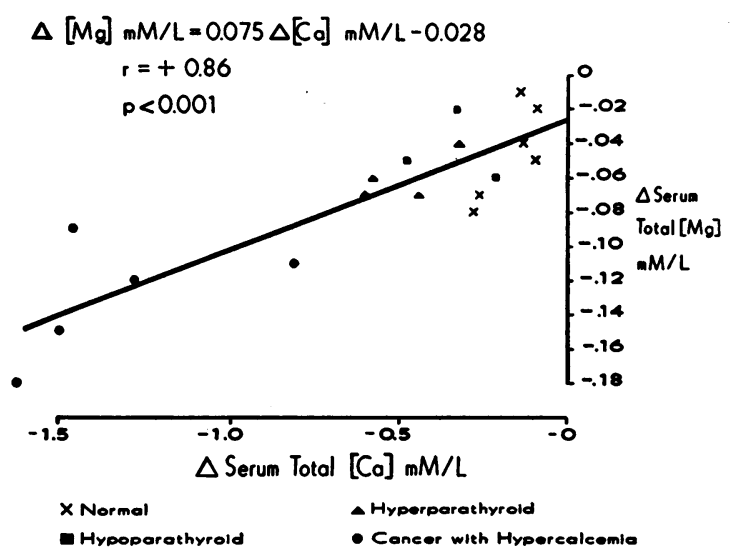

Fig. 7. The RELATIONSHIP BETWEEN THE OBSERVED REDUCTIONS IN TOTAL SERUM MAGNESIUM AND TOTAL SERUM CALCIUM AT THE END OF PHOSPHATE INFUSION.

from control either in the patients with hypoparathyroidism ( $\overline{\mathrm{d}}=-13 \pm 17, \mathrm{p}>0.3)$ or the patients with hyperparathyroidism $(\overline{\mathrm{d}}=-8 \pm 11$, $\mathrm{p}>0.2$ ).

Serum $[\mathrm{Mg}]$ was measured in 18 subjects before, during, and after phosphate infusion. Only small but significant reductions in serum $[\mathrm{Mg}]$, averaging $0.07 \pm 0.04$ mmole per $\mathrm{L}(\mathrm{p}<0.001)$, were induced by phosphate infusion in all subjects. Urinary $\mathrm{Mg}$ excretion was measured in 15 subjects (Table I) and fell from a mean of $4.7 \pm$ 2.1 mmoles per day during control observations to $2.8 \pm 1.3$ on the day of phosphate infusion $(\mathrm{p}<$ 0.01). Fecal $\mathrm{Mg}$ excretion was measured in the four balance studies and averaged $7.4 \pm 2.9$ mmoles per day during the control period and $8.7 \pm 3.0$ mmoles per day during the period in which phosphate was infused.

Phosphate infusion appeared to have a much smaller effect on serum $[\mathrm{Mg}]$. Although serum [Mg] fell slightly in every subject, the observed falls were only poorly correlated with the mean serum $[\mathrm{P}]$ during infusion or with the mean $[\mathrm{Mg}] \times[\mathrm{P}]$ molar product. Instead, changes in serum magnesium tended to follow the induced changes in serum calcium. Figure 7 shows a plot of the change in serum magnesium concentration during phosphate infusion as a function of the simultaneously observed change in serum total [Ca] concentration. Good correlation was found.

\section{Discussion}

Much evidence has been presented which indicates that precipitation of calcium phosphate salts from body fluids is initiated by the reaction $\mathrm{Ca}^{++}+$ $\mathrm{HPO}_{4}=\rightarrow \mathrm{CaHPO}_{4} \quad(11-13)$. The maximal product of the molar concentrations of these ions that can exist in solution without precipitation occurring defines their solubility product. When this solubility product is exceeded, precipitation begins. The solubility product for $\mathrm{CaHPO}_{4}$ has been estimated in vitro under physiologic conditions of temperature, ionic strength, $\mathrm{pH}$, and comparable $\mathrm{Ca} / \mathrm{P}$ molar concentration ratios by a number of investigators $(11,12,14)$, and their estimates range from 2.4 to $2.5 \times 10^{-6}$ mole per L. If, in the present studies, the fall in serum total [Ca] that occurred during phosphate infusion resulted from precipitation of $\mathrm{CaHPO}_{4}$, then the intercept on the ordinate of the regression line relating the fall in serum total [Ca] to the mean ultrafilterable $[\mathrm{Ca}] \times\left[\mathrm{HPO}_{4}{ }^{\circ}\right]$ molar product shown in Figure 3 should be an in vivo estimate of the $\mathrm{CaHPO}_{4}$ solubility product. The intercept value of $2.4 \times 10^{-6}$ mole per $\mathrm{L}$ is in good agreement with the in vitro estimates cited. In Figure 4, the intercept value on the ordinate of the regression line relating the fall in serum total [Ca] to the serum total $[\mathrm{Ca}] \times[\mathrm{P}]$ molar product is $4.6 \times$ $10^{-6}$ mole per $\mathrm{L}$. If this intercept value is expressed in miligrams per $100 \mathrm{ml}$, its numerical value becomes 58 and is in close agreement with the figure of 60 estimated by Albright and Reifenstein to represent the saturation point of serum with respect to calcium and phosphorus (15).

An earlier suggestion that elevation of the serum phosphorus lowered serum calcium only in hypercalcemic patients (16) was not confirmed, since the serum total [Ca] of normal subjects also fell during phosphate infusion in the present studies (Table II). Serum total [Ca] also fell in three patients with hypoparathyroidism, one of whom had a total thyroparathyroidectomy, and in three patients with breast cancer who had both adrenals and ovaries removed. These findings, taken with the fact that phosphate infusion could be shown to lower serum calcium within $3 \mathrm{~min}$ utes, lead us to conclude that hormonal factors are not involved in the reduction of. serum calcium that occurs during phosphate infusion. All of our data are consistent with the interpretation that phosphate lowers serum [Ca] by simple physicochemical precipitation of $\mathrm{CaHPO}_{4}$ as its solubility product is exceeded. 
The site or sites at which $\mathrm{CaHPO}_{4}$ precipitation occurs is of obvious clinical importance. Albright, Bauer, Claflin, and Cockrill (4) and Dent (5) cautioned that phosphate administered to hypercalcemic patients might result in soft tissue calcification or kidney stone formation. The studies of Gersh (17) suggest that calcium phosphate salts precipitate in the vascular system but are rapidly removed by macrophages in liver, spleen, and bone marrow and then presumably are slowly released again into the circulation. Goldsmith and Ingbar found extraskeletal calcifications at autopsy in several patients who had received phosphate (8). Calcium deposition in the vein into which phosphate was infused was noted roentgenologically in three of our patients with cancer and hypercalcemia. It is certainly also conceivable that as the $\mathrm{CaHPO}_{4}$ molar product increases, the net rate of release of calcium from bone decreases. Further studies of this possibility will be required.

The small reductions in serum $[\mathrm{Mg}]$ that occurred during phosphate infusion did not appear to be determined by a $[\mathrm{Mg}] \times[\mathrm{P}]$ molar product, but rather, they appeared to correlate with the magnitude of the reduction in serum [Ca] (Figure 7). This suggests that magnesium may coprecipitate with $\mathrm{CaHPO}_{4}$.

Since serum $[\mathrm{P}]$ had returned to control values within 24 hours after the phosphate infusion, the $\mathrm{CaHPO}_{4}$ solubility product was no longer exceeded in any subject beyond this time. Thus, other mechanisms must account for the delayed return of serum [Ca] to control levels in the patients with hypoparathyroidism, hyperparathyroidism, and cancer as compared to the normal subjects. In part, the apparent delay in the hypercalcemic patients was related to the higher control [Ca]. However, there is indirect evidence that the capacity to increase parathyroid hormone secretion may also have played a role. In the normal subjects two kinds of observations during and after phosphate infusion suggested a prompt increase in parathyroid hormone secretion in response to the reduction in serum [Ca] during infusions. First, although the greatly augmented filtered load of phosphate during infusion would have been expected to increase the absolute rate of tubular phosphate reabsorption (18), only a very slightly increased reabsorption was actually found during the infusion, and tubular phosphate reabsorption was significantly below control during the first recovery day (Figure 6). Second, during the first recovery day, urinary calcium excretion was less than control despite the fact that serum [Ca] had returned to, or even above, control levels. As would be expected in the absence of parathyroid function, the patients with hypoparathyroidism showed a sharp increase in tubular phosphate reabsorption during infusion. Similarly, the hypercalcemic patients also had marked increases in tubular phosphate reabsorption during phosphate infusion, which suggests a delayed response of the parathyroids to the induced fall of serum [Ca].

Clearly, lowering of serum [Ca] by intravascular precipitation of $\mathrm{CaHPO}_{4}$ is theoretically objectionable and potentially hazardous. The chances of significant damage to vital soft tissues by calcium precipitation are obviously a function of the total quantity of calcium precipitated and thus of the initial serum total [Ca], the total quantity of phosphate administered, and the rate at which it is infused. Because of these hazards it seems unreasonable to attempt to lower serum [Ca] to levels below which symptoms of calcium intoxication generally do not occur (about 3.0 mmoles per L). If an appropriate quantity of phosphate is infused over a 6-hour period, the present results suggest that symptomatic improvement can be attained without significant toxicity. ${ }^{3}$

${ }^{3}$ Our results suggest that it may be possible to predict the dose of phosphate that must be infused to induce a given fall in serum total [Ca]. The regression equation presented in Figure 4 states that (mean serum total [Ca] in millimoles per liter) $\times$ (mean serum [P] in millimoles per liter) during phosphate infusion $=4.6-3.8$ (change in serum total [Ca] in millimoles per liter at end of infusion). If we assume that $[\mathrm{P}]$ rises and total [Ca] falls in the serum in a linear fashion during infusion, the equation can be rewritten as: [ (initial serum total $[\mathrm{Ca}]+$ desired serum total [Ca] in millimoles per liter) $/ 2] \times[$ (initial serum $[P]+\operatorname{serum}[P]$ at end of infusion in millimoles per liter) $/ 2]=4.6-3.8$ (change in serum total [Ca] at end of infusion, millimoles per liter).

Since the initial serum total [Ca] is known and the final serum total [Ca] selected, the change in serum total [Ca] (a negative number) desired at the end of infusion is also known, and the equation can be solved for (initial serum $[\mathrm{P}]+$ final serum $[\mathrm{P}]$ ). Knowing the actual initial serum [P], we can easily obtain the required final serum $[P]$ and, hence, the desired increase in serum [P] at the end of infusion. In the present studies, approximately $80 \%$ of the administered phosphate was retained at the end of the infusions, and it appeared to be 


\section{Summary}

One to 2.8 mmoles phosphate per $\mathrm{kg}$ of body weight as neutral isotonic sodium-potassium phosphate was given intravenously to normal subjects, patients with hypoparathyroidism, and patients with hypercalcemia due to hyperparathyroidism or cancer.

Phosphate infusion lowered serum calcium in all subjects without causing simultaneous losses of calcium from the body. Evidence was presented which indicated that the calcium-lowering effect of phosphate was not hormonally mediated.

The studies permitted estimation of the in vivo $\mathrm{CaHPO}_{4}$ solubility product. The value of $2.4 \times$ $10^{-6}$ mole per $\mathrm{L}$ is in good agreement with many previous in vitro estimates.

Serum calcium concentration fell in direct proportion to the magnitude by which the $\mathrm{CaHPO}_{4}$ solubility product was exceeded during phosphate infusion.

The subsequent response to the fall in serum calcium levels induced by phosphate infusion appeared to depend upon the presence and responsiveness of the parathyroid glands.

\section{Acknowledgments}

We gratefully acknowledge the technical assistance of Jean Brock, Susan Frey, Stella Miller, and Susan Krogstaad, as well as the assistance of the staff of the Marquette Clinical Research Center.

\section{References}

1. Binger, C. Toxicity of phosphates in relation to blood calcium and tetany. J. Pharmacol. exp. Ther. 1917-1918, 10, 105.

distributed in a space approximately equal to $40 \%$ of body weight. Thus, the change in serum $[\mathrm{P}]$ at the end of infusion $=($ millimoles $P$ infused $\times 0.80) /($ kilograms body wt $\times 0.40)$, and the millimoles $P$ to be infused can be calculated.

These calculations have not yet been tested in other patients with hypercalcemia. Clearly, the presence of significant azotemia would alter the amount of phosphate retained in the body during infusion.
2. Salvesen, H. A., A. B. Hastings, and J. F. McIntosh. Blood changes and clinical symptoms following oral administration of phosphates. J. biol. Chem. 1924, 60, 311.

3. Bulger, H. A., H. H. Dixon, and D. P. Barr. The functional pathology of hyperparathyroidism. J. clin. Invest. 1930, 9, 143.

4. Albright, F., W. Bauer, D. Claflin, and J. R. Cockrill. Studies in parathyroid physiology. III. The effect of phosphate ingestion in clinical hyperparathyroidism. J. clin. Invest. 1932, 11, 411.

5. Dent, C. E. Some problems of hyperparathyroidism. Brit. med. J. 1962, 2, 1495.

6. Lemann, J., Jr., and A. A. Donatelli. Calcium intoxication due to primary hyperparathyroidism. A medical and surgical emergency. Ann. intern. Med. 1964, 60, 447.

7. Lemann, J., Jr., and M. P. Mehr. Sodium sulfate infusions and hypercalcemia. J. Amer. med. Ass. 1965, 194, 1126.

8. Goldsmith, R. S., and S. H. Ingbar. Inorganic phosphate treatment of hypercalcemia of diverse etiologies. New Engl. J. Med. 1966, 274, 1.

9. Toribara, T. Y., A. R. Terepka, and P. A. Dewey. The ultrafilterable calcium of human serum. I. Ultrafiltration methods and normal values. J. clin. Invest. 1957, 36, 738.

10. Chen, P. S., Jr., and W. F. Neuman. Renal excretion of calcium by the dog. Amer. J. Physiol. 1955, 180, 623.

11. Shear, M. J., and B. Kramer. Composition of bone. III. Physicochemical mechanism. J. biol. Chem. 1928, 79, 125.

12. Logan, M. A. Recent advances in the chemistry of calcification. Physiol. Rev. 1940, 20, 522.

13. Neuman, W. F., and M. W. Neuman. The Chemical Dynamics of Bone Mineral. Chicago, University of Chicago Press, 1958, p. 30.

14. McLean, F. C., and M. A. Hinrichs. The formation and behavior of colloidal calcium phosphate in the blood. Amer. J. Physiol. 1938, 121, 580.

15. Albright, F., and E. C. Reifenstein, Jr. The Parathyroid Glands and Metabolic Bone Disease. Baltimore, Williams \& Wilkins, 1948, p. 14.

16. Philpot, G. R. Calcium metabolism in humans. Thesis, University College Hospital Medical School, London, 1958.

17. Gersh, I. Histochemical studies on the fate of colloidal calcium phosphate in the rat. Anat. Rec. 1937, 70, 331.

18. Thompson, D. D., and H. H. Hiatt. Renal reabsorption of phosphate in normal human subjects and in patients with parathyroid disease. J. clin. Invest. 1957, 36, 550 . 